\title{
Framing vulnerability, risk and societal responses: the MOVE framework
}

\author{
J. Birkmann • O. D. Cardona • M. L. Carreño $\cdot$ A. H. Barbat $\cdot$ \\ M. Pelling $\cdot$ S. Schneiderbauer $\cdot$ S. Kienberger $\cdot$ M. Keiler $\cdot$ \\ D. Alexander $\cdot$ P. Zeil $\cdot$ T. Welle
}

Received: 11 March 2011/Accepted: 8 January 2013/Published online: 17 February 2013

(C) Springer Science+Business Media Dordrecht 2013

\begin{abstract}
The paper deals with the development of a general as well as integrative and holistic framework to systematize and assess vulnerability, risk and adaptation. The framework is a thinking tool meant as a heuristic that outlines key factors and
\end{abstract}

J. Birkmann $(\bowtie) \cdot$ T. Welle

United Nations University, Institute for Environment and Human Security, UN-Campus, HermannEhlers-Str. 10, 53113 Bonn, Germany

e-mail: birkmann@ehs.unu.edu

J. Birkmann

Department of Geography, University of Munich, 80333 Munich, Germany

O. D. Cardona

Instituto de Estudios Ambientales (IDEA), Universidad Nacional de Colombia, Campus Palogrande, Manizales, Colombia

\section{L. Carreño · A. H. Barbat}

Centre Internacional de Mètodes Numèrics en Enginyeria (CIMNE), Universitat Politècnica de Catalunya, Campus Norte UPC C/Gran Capitán S/N, 08034 Barcelona, Spain

M. Pelling

Department of Geography, King's College London, Strand, London WC2R 2LS, UK

S. Schneiderbauer

EURAC (European Academy, Institute for Applied Remote Sensing), Viale Druso, 1, 39100 Bolzano, Italy

S. Kienberger $\cdot$ P. Zeil

Interfaculty Department of Geoinformatics-Z_GIS, University of Salzburg, 5020 Salzburg, Austria e-mail: stefan.kienberger@sbg.ac.at

P. Zeil

e-mail: Peter.zeil@sbg.ac.at

M. Keiler

Institute of Geography, University of Bern, Hallerstrasse 12, 3012 Bern, Switzerland

D. Alexander

UCL Institute for Risk and Disaster Reduction, University College London, Gower Street, London

WC1E 6BT, UK 
different dimensions that need to be addressed when assessing vulnerability in the context of natural hazards and climate change. The approach underlines that the key factors of such a common framework are related to the exposure of a society or system to a hazard or stressor, the susceptibility of the system or community exposed, and its resilience and adaptive capacity. Additionally, it underlines the necessity to consider key factors and multiple thematic dimensions when assessing vulnerability in the context of natural and socio-natural hazards. In this regard, it shows key linkages between the different concepts used within the disaster risk management (DRM) and climate change adaptation (CCA) research. Further, it helps to illustrate the strong relationships between different concepts used in DRM and CCA. The framework is also a tool for communicating complexity and stresses the need for societal change in order to reduce risk and to promote adaptation. With regard to this, the policy relevance of the framework and first results of its application are outlined. Overall, the framework presented enhances the discussion on how to frame and link vulnerability, disaster risk, risk management and adaptation concepts.

\section{Keywords Vulnerability · Conceptual framework · Holistic approach · Exposure} Interventions

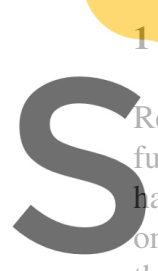

1 Introduction

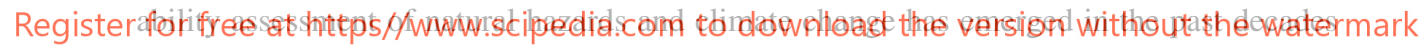
as an important research field (see, e.g., Maskrey 1984; Chambers 1989; Pelling 1997; Cardona 2001; Birkmann 2006a, b; Adger 2006; IPCC 2007; Bohle 2008; Bohle and Glade 2008; Oxfam America 2009) bringing together scientists from different disciplines (Fuchs, 2009). As there is no universal definition for vulnerability, various scientists from different backgrounds have given their own definitions, thus showing the lack of a common shared language. This paper outlines a framework for multi-dimensional, holistic vulnerability assessment that is understood as part of risk evaluation and risk management in the context of disaster risk management (DRM) ${ }^{1}$ and climate change adaptation (CCA). As a heuristic, the framework is a thinking tool to guide systematic assessments of vulnerability and to provide a basis for comparative indicators and criteria development to assess key factors and various dimensions of vulnerability. The framework has been developed within the context of the research project MOVE (Methods for the Improvement of Vulnerability Assessment in Europe; www.move-fp7.eu) sponsored by the European Commission within the framework of the FP 7 programme.

\footnotetext{
1 The term disaster risk management (DRM) also encompasses the concept of disaster risk reduction (DRR). Thus, these terms are used almost synonymously.
} 


\section{Background: Framing risk and vulnerability in the context of natural hazards and climate change adaptation}

\subsection{Definitions and perspectives}

The concept of vulnerability in DRM and CCA research is underpinned by multiple disciplinary theories based upon natural or social science epistemologies (IPCC 2012). This results in a range of paradigms for approaching vulnerability and is supported by qualitative and quantitative assessment methodologies (Pelling 2001; Birkmann 2006a, b; Fuchs 2009). Many assessment approaches characterize vulnerability according to the degree of susceptibility or fragility of communities, systems or elements at risk and their capacity to cope under hazardous conditions. The natural science research communities often focus on the quantification of different factors of vulnerability (e.g. Kienberger et al. 2009). An aim of these approaches - particularly regarding physical vulnerability - is to define and quantify damage ranges illustrated through vulnerability curves in order to help determine acceptable levels of potential losses (Papathoma-Köhle et al. 2010). Social science approaches often encompass a broad focus and examine, in particular, the likelihood that an individual household or a community will suffer harm or experience losses related to environmental hazards, as well as the context conditions that influence social vulnerability (DFID 1999; Wisner et al. 2004). In this context, Phillips and Fordham (2009) emphasize that social vulnerability to natural hazards is driven by social inequality and is deeply embedded in social structures that are often resistant to change (Phillips and

Fordham 2009): Besid

framework also deals

ssessments to natura.

DRR perspective by in
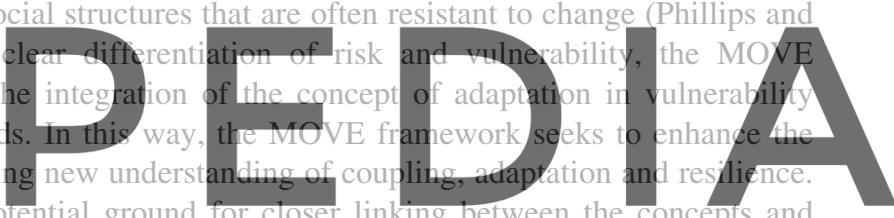

a potential ground for closer inking between the concepts and

Regissessment methodologies being developed in DRR and CCA communities. However, this does not mean that all approaches or concepts developed in Dersion without the watermark

monized, since they represent often two different interpretations of vulnerability and therefore are rather complementary approaches (see O'Brien et al. 2007; IPCC 2012). Before discussing the different components of the framework and the key factors of vulnerability in more depth, it is essential to outline the basic understanding of disaster risk and vulnerability as well as adaptation applied within the context of the framework.

\subsubsection{The social construction of risk}

The concept of vulnerability underscores the social construction of risk and is supported empirically by a range of studies applying vulnerability to help understand risk to hazards, including those with a focus on climate change (Aysan 1993; Blaikie et al. 1996; Wisner et al. 2004). Vulnerability refers to the propensity of exposed elements such as physical or capital assets, as well as human beings and their livelihoods, to experience harm and suffer damage and loss when impacted by single or compound hazard events (UNDRO 1980; Timmerman 1981; Maskrey 1984; Cardona 1986, 1990; Liverman 1990; Cannon 1994, 2006; Blaikie et al. 1996; UNISDR 2004, 2009; Birkmann 2006a, b, c; Cutter et al. 2003; Cutter and Finch 2008; Cutter et al. 2008). Alongside the socio-natural co-production of hazard and the social qualities of vulnerability (see, e.g., ICSU-LAC 2010), the ways in which different stakeholders perceive hazard, vulnerability and risk also need to be considered to understand the social construction of risk. Indeed, while there is broad 
agreement on the aspects of the social construction of risk (Chambers 1989; Cannon 1994; Lavell 1999; Wisner 2006; Carreño et al. 2007a, b; Cardona 2004), it is at the level of measurement where the challenge remains. The difficulty lies in assessing the various dimensions of vulnerability and its multi-faceted and dynamic nature (see, e.g., Birkmann 2006a, b, c; Birkmann and Fernando 2008).

\subsubsection{Risk and disasters}

While risk and vulnerability can be seen as continuums, a disaster is but a moment or materialization of these underlying conditions. Dynamic changes of vulnerability and hazard phenomena also mean that risk is non-static; it changes over time and these changes have to be considered when applying specific assessments, as well as when developing corrective (current risk) or prospective (future risk) interventions. Overall, disasters are the product of a complex relationship between the physical environment, both the natural and built environment, and society; its behaviour, function, organization and development, including human perception (Quarantelli 1998). The term disaster often refers to a social condition whereby the normal functioning of a social system has been severely interrupted by the levels of loss, damage and impact suffered (Cardona 1990; Alexander 1993, 2000; Birkmann 2006a, b). However, disaster can also function as a catalyst for change (see, e.g., Birkmann et al. 2010). Pelling and Dill (2010) demonstrate how disasters and crises can also catalyse reorganization and learning processes in communities or societies, often accelerating underlying policy and social trajectories. The concept of resilience has leveloped in differen

(e.g. Bonanno et al. 2

t al. 2003; Folke 20

vith disturbances and the
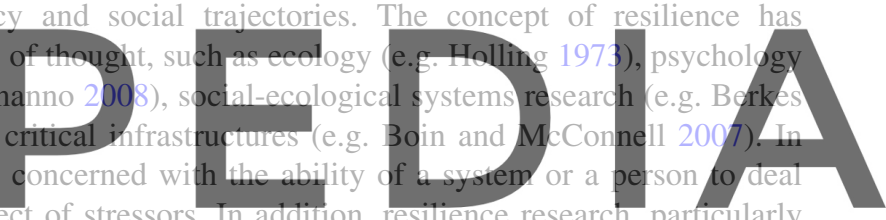

resilience research, particularly Register with regard to social-ecological systems or infrastructures, deals with the capacities of

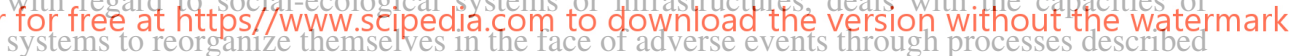

as revolt and remember. We refer to a part of the resilience discourse, in terms of clas-

sifying limited capacities to cope or to recover in the face of adverse consequences, as the 'lack of resilience', while at the same time 'improving resilience' is part of adaptation within our framework. Hence, the resilience concept is attributed to two core components of the framework: coping and adaptation.

\subsubsection{Adaptation and coping}

Adaptation also presents itself as a continuous property, with levels of adaptive capacity changing over time as the status of vulnerability components identified above change and the demands of a shifting risk environment alter the appropriateness of particular asset bundles for risk reduction (Pelling 2001). Such changes can be a result of disaster events but also everyday processes of development. It should be noted that adaptation is distinct from coping. Coping we see as an aspect of resilience that signifies the 'here and now' capacity and includes a set of actions available to those at risk. Coping in this way is part of the formula that determines vulnerability at any one moment in time. However, coping mainly deals with the conservation and protection of the current system and institutional settings (see Birkmann 2011). Adaptation, by contrast, denotes a longer-term and constantly unfolding process of learning, experimentation and change that feeds into vulnerability. Adaptation can be felt acting to shape all aspects of vulnerability and is observable 
through the systems and outcomes of learning - planned and spontaneous, pre- and postdisaster (Pelling 2010). This understanding of adaptation is commensurate with the emerging consensus from climate change (see Kelly and Adger 2000; Yohe and Tol 2002; Pelling 2010) where coping is seen to describe actions taken within existing constraints (including vision and knowledge), and adaptation signifies change in the framing institutions.

\subsection{Frameworks on how to systematize vulnerability in different communities}

In recent years, different frameworks have been developed to better systematize risk factors, different facets of vulnerability and resilience as well as the various alternatives of climate change adaptation. Thomalla et al. (2006) and Mitchell and van Aalst (2009) examine commonalities and differences between the CCA and DRM communities and identify key areas of convergence. They conclude that the two communities perceive the nature and timescale of the threat differently: if impacts due to climate change are surrounded by uncertainty, considerable knowledge and certainty exists about the event characteristics and exposures related to extreme environmental conditions based on historical experience. However, it has to be acknowledged that climate change challenges the historical knowledge of natural hazard events, particularly due to the modification of frequency and intensity of such events (Keiler et al. 2010).

Climate change adaptation increasingly places emphasis on improving the capacity of governments and communities to address existing vulnerabilities to current climate variability and climatic extremes (Thomalia et al. 2006). Echoing the long-standing concerns of the disaster management

management (e.g. Hewitt 1983; Burton munity, O'Brien et al adaptive capacity and technical measures. Furthermore Birkmann and von Teichman Register for free at https s wWw scipedia.com to download the version without the watermark spatial, temporal and functional scales applied within their research. Additionally, Romieu et al. (2010) examined different frameworks and assessment approaches used within CCA and DRM. They concluded that differences are particularly linked to process (stress versus shock), scale (temporal, functional and spatial), assessment approach (statistical versus prospective), and levels of uncertainty.

\subsubsection{Different frameworks to systematize and define vulnerability}

The DRM and CCA communities share common roots in social and political science; however, four distinct approaches to understanding vulnerability and risk can be identified. The four approaches are not contradictory but rather approach risk from a specific viewpoint and with particular ends in mind-from the unearthing of systems linkages from the global to the local to the search for quantifiable risk measures. This section provides a brief overview of each approach to help illustrate the key differences and similarities behind these ways of conceptualizing and measuring risk and its components. Each approach has been considered in the production of the integrated framework proposed in this paper. The four approaches can be distinguished between those that are rooted in (1) political economy; (2) social-ecology; (3) vulnerability and disaster risk assessment from a holistic view; and (4) climate change systems science. 
The political economy approach can be illustrated by the pressure and release (PAR) model published in Blaikie et al. (1994) and Wisner et al. (2004). This links vulnerability to unsafe conditions and discrete risk in a continuum of vulnerability that connects local risk to wider national and global shifts in the political economy of resources and political power. Associated with this approach and operating across development studies more generally is the Sustainable Livelihood Framework (see DFID 1999). Applied in risk contexts most commonly to help understand household impacts and coping when faced with food insecurity, the framework successfully unpacks the range of assets that are at risk and can be used to generate security from disaster. Importantly from a political economy perspective, the framework directs attention to the ways in which the organizational, institutional and political context helps to shape local capacity-but also recognizes that these structures are reproduced through the actions of individuals and households. The social-ecology perspective emphasizes the need to focus on coupled human-environmental systems when dealing with the assessment of risk. The best-known visualization of this approach has been developed and published by Turner et al. (2003). Compared to political economy, the perspective of social-ecology stresses the transformative qualities of society with regard to nature - and also the effects of changes in the environment on social and economic systems. It argues that the exposure and susceptibility of a system can only be adequately understood if these coupling processes and interactions are addressed.

Comprehensive perspectives from vulnerability and disaster risk assessment have tried to develop an integrated explanation of risk. These approaches particularly differentiate exposure, susceptibility and societal response capacities or the lack of resilience (see Cardona 1999a, b, 200 2007a, b; Birkmann lement of these approact ynamic and that vulnerability assessment ciencies, but rather also take into account the potential feedback loops and intervention tools that exist or can be developed in order to reduce vulnerability Morepver, the for free at https//Www.scipedia.com to download the version without the watermark perspective of sustainable development into the assessment of vulnerability (Birkmann 2006a, b).

The fourth school of thought emerged within the context of CCA (see, e.g., Füssel and Klein 2006). Most of these approaches focus closely on the definition of vulnerability used by the IPCC. Vulnerability in this regard is understood as a function of exposure, sensitivity $^{2}$ and adaptive capacities (Füssel 2007a, b; McCarthy et al. 2001; IPCC 2007; O'Brien et al. 2008a, b). These frameworks, however, differ from the understanding of vulnerability in the DRM community in that they take into account the rate and magnitude of climate change. This introduces a critical distinction between the understanding of vulnerability within climate change and the other schools of thought discussed above. The concept of vulnerability here includes external environmental factors of shock or stress. Hence, in this view, the magnitude and frequency of potentially hazardous events is to be included in the calculation of vulnerability to climate change, and hence, the vulnerability concept shifts towards a risk definition.

\footnotetext{
${ }^{2}$ Interestingly, the term sensitivity means different things to different communities; however, the actual factors used to assess sensitivity of a system in CCA can be closely linked to factors that are used to characterize susceptibility or fragility in the DRM context.
} 


\section{A multi-dimensional and holistic framework for assessing vulnerability: the MOVE framework}

\subsection{Goals of the framework}

A key goal when developing the MOVE framework was to provide an improved conceptualization of the multi-faceted nature of vulnerability, accounting for key causal factors such as exposure, susceptibility, lack of resilience (lack of societal response capacities) as well as for the different thematic dimensions of vulnerability: physical, social, ecological, economic, cultural and institutional. Additionally, the framework incorporates the concept of adaptation into disaster risk management, and therewith explicitly differentiates coping from adaptation.

The MOVE conceptual framework (see Fig. 1) underlines that hazards are of natural or socio-natural origin while vulnerability in its multi-faceted nature is mainly linked to societal conditions and processes.

\subsection{Key factors of vulnerability within the MOVE framework}

At its core, the MOVE framework differentiates key factors of vulnerability and shows the different thematic dimensions of vulnerability. The key factors of vulnerability are defined as follows:
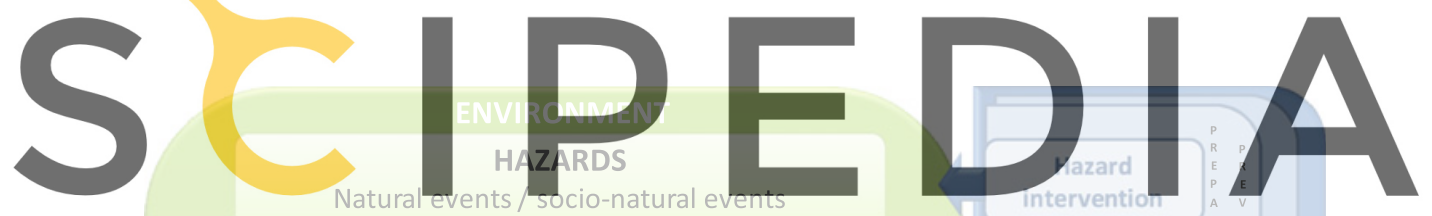

Register for free at https//wwh

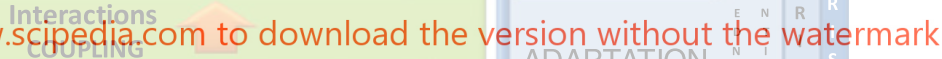
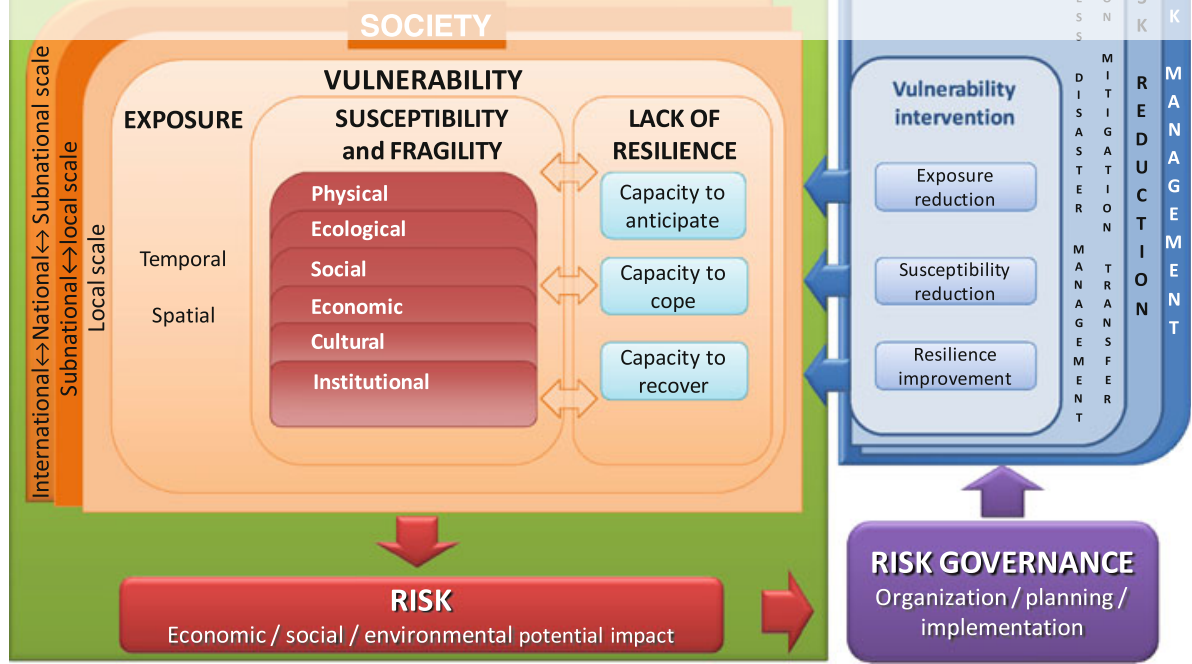

Fig. 1 The MOVE framework (own figure, based particularly on concepts of Cardona 1999a, p. 65; Cardona 2001; Turner et al. 2003; Bogardi and Birkmann 2004; IDEA 2005; Birkmann 2006a, b; Carreño et al. 2007a) 
1. Exposure describes the extent to which a unit of assessment falls within the geographical range of a hazard event. Exposure extends to fixed physical attributes of social systems (infrastructure) but also human systems (livelihoods, economies, cultures) that are spatially bound to specific resources and practices that may also be exposed. Exposure is then qualified in terms of spatial and temporal patterns.

2. Susceptibility (or fragility) describes the predisposition of elements at risk (social and ecological) to suffer harm. Although susceptibility and fragility imply subtle differences in various concepts, we mainly use them synonymously within the meta-framework in order to emphasize the core differences between exposure, susceptibility and lack of resilience. In this context, susceptibility (or fragility) can be calculated and addressed often independent of exposure.

3. Lack of resilience or societal response capacity is determined by limitations in terms of access to and mobilization of the resources of a community or a social-ecological system in responding to an identified hazard. This includes pre-event risk reduction, in-time coping and post-event response measures. Compared to adaptation processes and adaptive capacities, these capacities focus mainly on the ability to maintain the system in the light of a hazard event impacting the system or element exposed. In this sense, the capacity to anticipate, the capacity to cope and the capacity to recover can include significant changes to existing practices around a referent hazard event/ scenario but does not include learning based on the potential for future change in hazard and vulnerability contexts. However, the concept of resilience also includes learning and reorganization processes and therefore is positioned as a sub-component

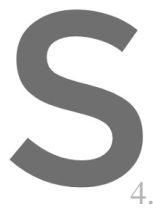
of the adaptation box. Compared to the
existing capacities, the adaptation box a
system to learn from the past disasters
future changes in hazards as well as vu Hazard is used to describe the potential occurrence of natural, socio-natural or

anthropogenic events that may have physical social. economic and enyironmental impact in a given area and over a period of time. Therefore, hazard is defined by the

potentiality of geodynamics or hydro-meteorological processes to cause effects upon exposed elements. In addition, the concept of coupling emphasizes the framework's assertion that any defined hazard is given form and meaning by interaction with social systems, and similarly, social systems are influenced by their actual and perceived hazard context.

\subsubsection{Multi-dimensional vulnerability}

In addition to key factors of vulnerability, core thematic dimensions of vulnerability have to be addressed within a holistic assessment process. Key thematic components are:

- Social dimension: propensity for human well-being to be damaged by disruption to individual (mental and physical health) and collective (health, education services, etc.) social systems and their characteristics (e.g. gender, marginalization of social groups).

- Economic dimension: propensity for loss of economic value from damage to physical assets and/or disruption of productive capacity.

- Physical dimension: potential for damage to physical assets including built-up areas, infrastructure and open spaces.

- Cultural dimension: potential for damage to intangible values including meanings placed on artefacts, customs, habitual practices and natural or urban landscapes. 
- Environmental dimension: potential for damage to all ecological and bio-physical systems and their different functions. This includes particular ecosystem functions and environmental services (see, e.g., Renaud 2006) but excludes cultural values that might be attributed.

- Institutional vulnerability: potential for damage to governance systems, organizational form and function as well as guiding formal/legal and informal/customary rules-any of which may be forced to change the following weaknesses exposed by disaster and response.

The majority of assets and systems exposed to hazard will exhibit more than one dimension of vulnerability.

\subsubsection{Risk and risk governance}

In contrast to vulnerability—risk is defined as the probability of harmful consequences or losses resulting from interactions between hazard and vulnerable conditions. It is the potential for physical, social, economic, environmental, cultural or institutional consequences or losses, in a given area and over a period of time (see UNISDR 2004). In addition, risk governance is linked to decisions and actions performed by formal stakeholders such as governments or different governmental institutions and informal stakeholders (individual households) that include tasks on risk reduction, prevention, mitigation and transfer and also preparedness and disaster management (see, e.g., Renn 2008).
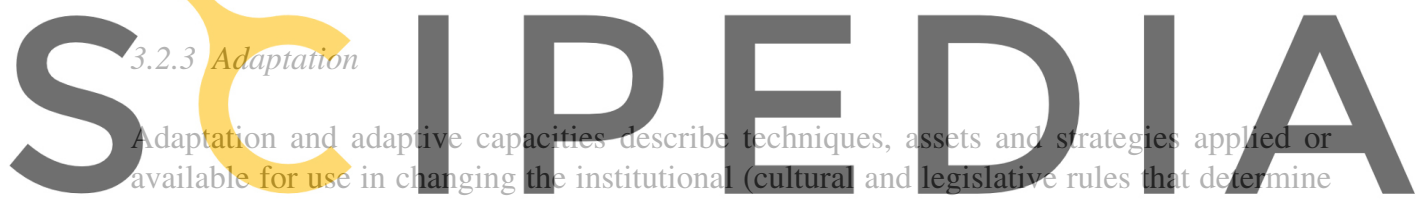

rights and responsibilities) and structural (balance and distribution of assets and infor-

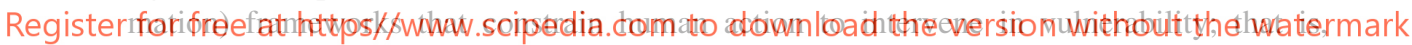

manage exposure, susceptibility and resilience at any one moment in time. In this regard,

resilience building and improvement is seen as a component of adaptation. Compared to capacities to cope or to recover (classified as the 'lack of resilience'), resilience in the adaptation box refers to learning and reorganization processes in the light of potential future changes and hazards, as well as potential changes in vulnerability. Consequently, the concept of resilience is differentiated into (1) a more reactive part that refers to the lack of resilience, while (2) the ability to learn and to reorganize in anticipation of future changes (proactive actions) is linked to the notion of adaptation. While coping capacities and resilience are primarily linked to capacities that help to maintain the current status of the systems under stress, adaptation as a concept implies actions aimed at making more profound change in socio-ecological relations (see, e.g., Pelling 2010; Birkmann 2011).

\subsection{Underlying thoughts: feedback loops, system thinking and nonlinearity}

In terms of the underlying systematization of different aspects, the framework refers in a theoretical context to general systems theory, cybernetics and interlinked systems theory (see, e.g., Vester 2008). It underlines that vulnerability and risk are embedded in processes and therefore have a dynamic nature - they change over time. Although this has been stressed by different authors in the past (see, e.g., Keiler et al. 2006; Bründl et al. 2010), many vulnerability and risk assessment approaches in the context of natural hazards and 
climate change still do not account for capacities to cope and to adapt. Compared with the linear understanding of feedback and response processes held by cybernetic theory and the idea that systems can be steered more or less easily, the MOVE framework emphasizes that nonlinearity, complexity and emergence are key characteristics of disaster risk systems and their various processes. This movement towards complex systems theory can build on a legacy of engagement with cybernetics in the geographical tradition of hazards studies (Cardona 2001, 2011; Hilhorst 2004; Pelling 2010). The analytic leverage that cybernetics brought to social-natural interactions is perhaps best signified by their introduction to the notion of adaptation (Vayda and McCay 1975), which was used to describe changes in the status of systems elements as energy and material flowed between natural and social systems. This limited view of adaptation had the advantage of being quantifiable. Many elements of adaptation introduced in this period reoccur in contemporary debates on adaptation to climate change where systems theory has been resurgent. Critics argued that while the cybernetic approach had made progress in providing a framework that recognized social context as a mediating pressure on the environment, it did not have the conceptual tools to analyse these relationships. Deeper social relations of production and power were not included.

Current perspectives on adaptation, vulnerability and risk to climate change developed from systems thinking within the socio-ecological systems school have made some advances in integrating power dynamics into models of risk (see, e.g., Gunderson and Holling 2002). The policy warning is that social systems will change in time driven either by environmental crisis or pre-emptive risk management (Handmer and Dovers 1996). It is possible to insert power tures and agency in cyct

onditions institution cological crises (Galaz
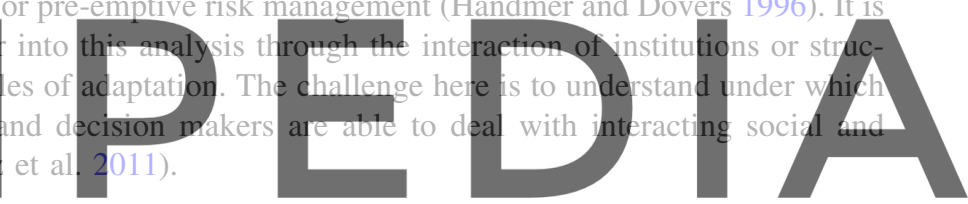

Register for free at https//www.scipedia.com to download the version without the watermark

The outline of preliminary criteria and indicators developed within the MOVE framework shows that the different terms and elements of the framework can be operationalized. However, the constraints and limits of applying the framework would first become evident. The selected examples include vulnerability to floods and earthquakes. In this regard, special emphasis is given to the differentiation of hazard characteristic, exposure, susceptibility and societal response capacities (lack of resilience and adaptation) (see Table 1a, b). The examples show that most of the components of the MOVE framework can be applied as a basis for developing and differentiating indicators and criteria for vulnerability assessment. Compared to flood-related vulnerability, the case of economic vulnerability to earthquakes in Barcelona shows that through an analysis of property values at the local level, average annual losses can be calculated. Thus, the assessment of social vulnerability using low-income groups and low-income urban areas as proxies shows that the application of the MOVE framework is also possible in the case of the earthquakeprone city of Barcelona. Furthermore, the lack of institutional resilience was assessed by using expert interviews and a benchmark index for preparedness and the capacity of different agencies to deal with earthquake-related disasters (rescue teams, fire brigades, etc.) in Barcelona (see Table 1b). 
Table 1 Application and illustration of the MOVE framework-assessment criteria and indicators

\begin{tabular}{|c|c|c|c|c|c|}
\hline $\begin{array}{l}\text { Components } \\
\text { of the MOVE } \\
\text { framework }\end{array}$ & Defined indicator & Measuring concept and unit & Data/information needed & Challenges & $\begin{array}{ll}\text { Quantitative } & \text { Qualitative } \\
\text { indicator } & \text { indicator }\end{array}$ \\
\hline
\end{tabular}

Floods: social dimension of vulnerability on city district level for Cologne

Exposure $\quad$ Exposed people $\quad$ Number of people who are living

Susceptibility Ability to evacuate

Experience with floods Percentage of people who have

Lack of resilience

(capacity to

cope)

Adaptation
Insurance regarding damages due to

natural hazards,

particularly floods

Flood protection agency in flood-prone areas, population data were intersected with flood data

Percentage of people who are able to evacuate themselves and others without external help (estimated based on age structure per $\mathrm{HH}$ and

information about invalid people) experience with floods

(estimated based on the duration of residence of a specific household in a flood-exposed area) of residence in the specific area

Percentage of $\mathrm{HH}$ with insurance against damage due to natural hazards

Qualitative information about the performance of the early warning system through expert interviews
Population density

Geodata indicating the flooded areas based on hydrological models

HH types

Information about invalid people (micro census)

Geodata indicating the flooded areas based on hydrological models

Geodata indicating the flooded areas based on hydrological

models

number of $\mathrm{HH}$ and their duration (classes)

Data availability

acquisition

for hydrological

$$
\text { modelling }
$$

Data availability on

different scales

Insurance information per $\mathrm{HH}$ through $\mathrm{HH}$ surveys

Data availability on different scales

$\mathrm{HH}$ survey cost and time consuming

Knowledge on how institutions provide information regarding

Valuation of operational capability 
Table 1 continued

\begin{tabular}{|c|c|c|c|c|c|c|}
\hline $\begin{array}{l}\text { Components } \\
\text { of the MOVE } \\
\text { framework }\end{array}$ & Defined indicator & Measuring concept and unit & Data/information needed & Challenges & $\begin{array}{l}\text { Quantitative } \\
\text { indicator }\end{array}$ & $\begin{array}{l}\text { Qualitative } \\
\text { indicator }\end{array}$ \\
\hline
\end{tabular}

Earthquake, Barcelona urban area case study

Hazard
Spectral acceleration and spectral

displacement of more

than 2,000 stochastic

seismic scenarios

affecting the city

Exposed buildings

Inventory and taxonomy of buildings of the city and distribution by district and other spatial units of analysis

Exposed people

Number of people living and working in the buildings of the city

Potential building damage

Susceptibility physical

dimension,

economic

dimension

Probabilistic intensity measure

the seismic demand to each

exposed building, according to

its period of vibration percentage of the property value
Earthquake sources (faults),

catalogue of historical events

(to generate stochastic

scenarios), attenuation curves,

site effects factors due to

classification of soils in the city

Cadastral information including

building characteristics (age,

construction materials, height

or number of stories, type of

structure, etc. for typology

classification) and the property

value

Average occupation during day

(or nights) depending on

building use (residential,

office, commercial, industrial,

etc.)

Building vulnerability functions

to relate the spectral

$\mathrm{X}$

acceleration or displacement

with the potential damage in

the buildings according to the

building typology 
Table 1 continued

\begin{tabular}{|c|c|c|c|c|c|c|}
\hline $\begin{array}{l}\text { Components } \\
\text { of the MOVE } \\
\text { framework }\end{array}$ & Defined indicator & Measuring concept and unit & Data/information needed & Challenges & $\begin{array}{l}\text { Quantitative } \\
\text { indicator }\end{array}$ & $\begin{array}{l}\text { Qualitative } \\
\text { indicator }\end{array}$ \\
\hline \multirow{6}{*}{$\begin{array}{l}\text { Social } \\
\text { dimension, } \\
\text { economic } \\
\text { dimension }\end{array}$} & $\begin{array}{l}\text { Expected human losses: } \\
\text { premiums or } \\
\text { expected casualties, } \\
\text { injuries, homeless, } \\
\text { jobless }\end{array}$ & $\begin{array}{l}\text { Potential effects on population } \\
\text { (human losses) expressed as a } \\
\text { percentage of the people } \\
\text { occupation }\end{array}$ & $\begin{array}{l}\text { Human vulnerability functions to } \\
\text { related the building damage } \\
\text { with the potential casualties, } \\
\text { injuries, homeless, jobless in } \\
\text { the buildings according to the } \\
\text { building occupation and } \\
\text { typology }\end{array}$ & & & \\
\hline & $\begin{array}{l}\text { Low-income people } \\
\text { neighbourhood area }\end{array}$ & $\begin{array}{l}\text { Financial deprivation. Percentage } \\
\text { of the total area corresponding to } \\
\text { poor neighbourhoods }\end{array}$ & $\begin{array}{l}\text { Low-income and slum built area } \\
\text { Total built area of the district }\end{array}$ & & $\mathrm{X}$ & \\
\hline & Mortality rate & $\begin{array}{l}\text { Healthcare access. Number of } \\
\text { deaths each } 10,000 \text { inhabitants }\end{array}$ & Statistical information of the city & & $\mathrm{X}$ & \\
\hline & Delinquency rate & $\begin{array}{l}\text { Social fragmentation and } \\
\text { degradation. Number of crimes } \\
\text { each } 100,000 \text { inhabitants }\end{array}$ & Statistical information of the city & & $\mathrm{X}$ & \\
\hline & Social disparity & $\begin{array}{l}\text { Inequality, long-term } \\
\text { unemployment, poverty. Index } \\
0-100\end{array}$ & $\begin{array}{l}\text { Expert opinion related to welfare } \\
\text { recipients, homeless persons, } \\
\text { lack of basic needs and human } \\
\text { development }\end{array}$ & $\begin{array}{l}\text { Difficulties to get robust } \\
\text { indicators of social } \\
\text { disparities in the spatial } \\
\text { units used; desirable to } \\
\text { reflect high resolution } \\
\text { social fragility }\end{array}$ & & $\mathrm{X}$ \\
\hline & Population density & $\begin{array}{l}\text { Overcrowding, tenement housing. } \\
\text { Inhabitants per square kilometre } \\
\text { of built area }\end{array}$ & $\begin{array}{l}\text { Population density on city district } \\
\text { level }\end{array}$ & & $\mathrm{X}$ & \\
\hline
\end{tabular}


Table 1 continued

\begin{tabular}{|c|c|c|c|c|c|c|}
\hline $\begin{array}{l}\text { Components } \\
\text { of the MOVE } \\
\text { framework }\end{array}$ & Defined indicator & Measuring concept and unit & Data/information needed & Challenges & $\begin{array}{l}\text { Quantitative } \\
\text { indicator }\end{array}$ & $\begin{array}{l}\text { Qualitative } \\
\text { indicator }\end{array}$ \\
\hline \multirow{6}{*}{$\begin{array}{l}\text { Resilience } \\
\text { «Lack of» } \\
\text { (institutional } \\
\text { dimension, } \\
\text { social } \\
\text { dimension) }\end{array}$} & Hospital beds & $\begin{array}{l}\text { Preparedness, capacity to cope. } \\
\text { Number of hospital beds each } \\
1,000 \text { inhabitants }\end{array}$ & Statistical data of the city & & $\mathrm{X}$ & \\
\hline & $\begin{array}{l}\text { Health human } \\
\text { resources }\end{array}$ & $\begin{array}{l}\text { Preparedness, capacity to cope. } \\
\text { Health human resources each } \\
1,000 \text { inhabitants }\end{array}$ & Statistical data of the city & & $\mathrm{X}$ & \\
\hline & Public space & $\begin{array}{l}\text { Capacity to cope and recover. } \\
\text { Percentage of available public } \\
\text { space of the total area }\end{array}$ & Statistical data of the city & & $X$ & \\
\hline & $\begin{array}{l}\text { Rescue and firemen } \\
\text { manpower }\end{array}$ & $\begin{array}{l}\text { Preparedness, capacity to cope. } \\
\text { Rescue and firemen manpower } \\
\text { each } 10,000 \text { inhabitants }\end{array}$ & Statistical data of the city & & $X$ & \\
\hline & Development level & $\begin{array}{l}\text { Capacity to cope and recover. } \\
\text { Benchmark index using four } \\
\text { levels: } 1-2-3-4\end{array}$ & $\begin{array}{l}\text { Expert opinion on quality of life, } \\
\text { welfare, economic health, } \\
\text { urban planning and governance } \\
\text { in the district }\end{array}$ & $\begin{array}{l}\text { Difficulties to find experts } \\
\text { to provide a confident } \\
\text { qualification }\end{array}$ & & $\mathrm{X}$ \\
\hline & Emergency planning & $\begin{array}{l}\text { Preparedness, capacity to cope. } \\
\text { Benchmark index using three } \\
\text { levels: } 0-1-2\end{array}$ & $\begin{array}{l}\text { Expert opinion of the level of } \\
\text { preparedness and emergency } \\
\text { response capacity }\end{array}$ & $\begin{array}{l}\text { Difficulties to find experts } \\
\text { to provide an impartial } \\
\text { qualification }\end{array}$ & & $\mathrm{X}$ \\
\hline
\end{tabular}




\section{Challenges and outlook}

Against the background of the diverse approaches and assessment methods used in DRM and CCA, the MOVE framework presented in this paper shows that vulnerability assessments in the context of natural hazards and climate change can be based on a certain consensus between different approaches. That means the analysis of vulnerability in both DRM and CCA considers often four key factors that determine vulnerability: (a) exposure to a hazard or stressor; (b) susceptibility (or fragility); (c) societal response capacities or lack of resilience and (d) adaptive capacities. However, some approaches consider exposure as an own factor next to vulnerability (see IPCC 2012) or as a hybrid between vulnerability and the natural hazard or physical event.

As a heuristic, the MOVE framework is a thinking tool to guide systemic assessment processes and the development of indicators, which for example could be described in specific guiding documents (Vichon et al. 2011). However, the framework does not provide a specific assessment method (qualitative or quantitative) or a pre-defined list of indicators. Rather, it outlines key factors and different dimensions of vulnerability that can serve as a basis for a systematic operationalization of vulnerability (see also Table 1). The framework stresses the fact that many interactions that shape vulnerability are dynamic (change over time) and characterized by nonlinearity and place-specific factors. Thus, the application of the framework has to consider the place-specific characteristics that influence vulnerability and its components as well as the coupling processes between social and environmental systems. In addition, this framework considers different scales: not only recognizing the fact that certain characteristics are typical or only valid at a certain scales (e.g. community versus global assessment), but also reflecting the fact that specific scales (spatial and temporal scales) correspond with different needs of stakeholders and institutions operating at different times and spatial ranges. The specific translation of the framework into concrete measures also depends on the research object or subject (social group, physical buildings, socio-ecological systems) and the hazard context. An important benefit of the framework can be seen in the ability to straddle multiple approaches and epistemologies in natural and social sciences and disaster risk management. Instead of focusing solely on the deficiencies of a community or incapacities of different social groups or social-ecological systems, the concept and its application shows that vulnerable groups or systems have also developed capacities that help them to survive or deal with changing environmental conditions.

To achieve coherence in the framework required the assertion of particular terms to describe components of vulnerability, some of which are described by a range of terms under different traditions. This clarification is not intended to undermine alternative use of terms or different terminology elsewhere but is a response to the lack of coherence across the current work on risk, vulnerability and adaptation. An example is the use of the term susceptibility, which some disaster risk assessment tools focusing on physical and building vulnerability describe as 'fragility'.

Lastly, the framework is easy to understand for different disciplines and therefore enables and promotes the communication process between different communities, particularly between the DRM and CCA community. In this context, the framework also has a strong relevance for policy makers that aim to base their decisions on a comprehensive and integrative approach of vulnerability and risk identification. For example, the EU Flood Directive on Assessment and Management of Flood Risks (2007/60/EC) and the subsequent EU Flood Directive Implementation Strategy lack to address vulnerability in a comprehensive and integrative approach. In this regard, the framework could be used to 
inform agencies responsible for carrying out flood risk maps in the context of the directive, in terms of providing them with a broader overview of the various dimensions and key factors that should be considered within a holistic approach.

However, challenges remain with regard to the implementation of the framework and its key components in highly diverse hazards and cultural context situations. In particular, the intangible factors that determine institutional or cultural vulnerability are difficult to capture and to assess. However, the selected examples shown in the table provide an illustration on how one can capture these rather intangible aspects within such assessments. Hence, it is proven that these facets of vulnerability can be translated into assessable criteria and indicators.

\section{References}

Adger WN (2006) Vulnerability. Glob Environ Change 16(3):268-281

Alexander DE (1993) Natural disasters. UCL Press Limited, London

Alexander DE (2000) Confronting catastrophe. Terra Publishing, Harpenden

Aysan Y (1993) Vulnerability assessment. In: Merriman P, Browitt CWA (eds) Natural disasters: protecting vulnerable communities. Thomas Telford, London

Barbat AH, Carreño ML, Cardona OD, Marulanda MC (2011) Evaluación holística del riesgo sísmico en zonas urbanas. Revista Internacional de Métodos Numéricos para Cálculo y Diseño en Ingeniería 27:3-27. Available from: http://www.cimne.com/tiendaCIMNE/productoscon.asp?id_prod=1857

Berkes F, Colding J, Folke C (2003) Introduction. In: Berkes F, Colding J, Folke C (eds) Navigating socialecological systems: building resilience for complexity and change. Cambridge University Press, Boston

Birkmann J (ed) (2006a) Measuring vulnerability to natural hazards-towards disaster resilient societies. United Nations University Press, Tokyo

Birkmann J (2006b) Measuring vulnerability to promote disaster-resilient societies: conceptual frameworks and definitions. In: Birkmann J (ed) Measuring vulnerability to natural hazards: towards disaster resilient societies. United Nations University Press, Tokyo, pp 9-54

Birkmann J (2006c) Indicators and criteria for measuring vulnerability: theoretical bases and requirements. In: Birkmann J (ed) Measuring vulnerability to natural hazards-towards disaster resilient societies. United Nations University Press, Tokyo, pp 55-77

Birkmann J (2011). Regulation and coupling of society and nature in the context of natural hazardsdifferent theoretical approaches and conceptual frameworks and their applicability to analyse socialecological crises phenomena. In: Brauch HG, Oswald Spring U, Mesjasz C, Grin J, Kameri-Mbote P, Chourou B, Dunay P, Birkmann J (eds) Coping with global environmental change, disasters and security - threats, challenges, vulnerabilities and risks. Hexagon Series on Human and Environmental Security and Peace, vol 5. Springer, Berlin

Birkmann J, Fernando N (2008) Measuring revealed and emergent vulnerabilities of coastal communities to tsunamis in Sri Lanka. Disasters 32(1):82-104

Birkmann J, von Teichman K (2010) Integrating disaster risk reduction and climate change adaptation: key challenges-scales, knowledge, and norms. Sustain Sci 5(2):171-184

Birkmann J, Buckle P, Jaeger J, Pelling M, Setiadi N, Garschagen M, Fernando N, Kropp J (2010) Extreme events and disasters: a window of opportunity for change? Analysis of changes, formal and informal responses after mega-disasters. Nat Hazards 55(3):637-655

Blaikie P, Cannon T, Davis I, Wisner B (1994) At risk: natural hazards, people, vulnerability, and disasters. Routledge, London

Blaikie P, Cannon T, Davis I, Wisner B (1996) Vulnerabilidad, el entorno social de los desastres. La REDITDG, Bogota

Bogardi J, Birkmann J (2004) Vulnerability assessment: the first step towards sustainable risk reduction. In: Malzahn D, Plapp T (eds) Disasters and society-from hazard assessment to risk reduction. Logos, Berlin, pp 75-82

Bohle H-G (2008) Krisen, Katastrophen, Kollaps-Geographien von Verwundbarkeit in der Risikogesellschaft. In: Kulke E, Popp H (eds) Umgang mit Risiken. Katastrophen-Destabilisierung-Sicherheit. Deutscher Geographentag 2007, Bautzen. Lausitzer Druck- und Verlagshaus GmbH, Bayreuth, pp 69-82 
Bohle H-G, Glade T (2008) Vulnerabilitätskonzepte in Sozial- und Naturwissenschaften. In: Felgentreff C, Glade T (eds) Naturrisiken und Sozialkatastrophen. Spektrum Verlag, Berlin, pp 99-119

Boin A, McConnell A (2007) Preparing for critical infrastructure breakdowns: the limits of crisis management and the need for resilience. J Contingencies Crisis Manag 15(1):50-59

Bonanno G (2008) Loss, trauma, and human resilience: have we underestimated the human capacity to thrive after extremely aversive events? Am Psychol 59(1):20-28

Bonanno GA, Galea S, Bucciarelli A, Vlahov D (2006) Psychological Resilience after Disaster: new York City in the Aftermath of the September 11th Terrorist Attack. Psychol Sci 17(3):181-186

Bründl M, Bartelt P, Schweizer J, Keiler M, Glade T (2010) Snow avalanche risk analysis-review and future challenges. In: Alcantara-Ayla I, Goudie A (eds) Geomorphological hazards and disaster. Cambridge University Press, Boston, pp 49-61

Burton I, Kates RW, White GF (1993) The environment as hazard. Guildford Press, London

Cannon T (1994) Vulnerability analysis and the explanation of 'natural' disasters. In: Varley A (ed) Disasters, development and environment. Wiley, Chichester, pp 13-29

Cannon T (2006) Vulnerability analysis, livelihoods and disasters. In: Ammann WJ, Dannenmann S, Vulliet L (eds) Risk 21: coping with risks due to natural hazards in the 21st century. Taylor and Francis Group plc, London, pp 41-49

Cardona OD (1986) Estudios de Vulnerabilidad y Evaluación del Riesgo Sísmico: Pla-nificación Física y Urbana en Áreas Propensas. Boletín Técnico de la Asociación Colombiana de Ingeniería Sismica 33(2):32-65

Cardona OD (1990) Terminología de Uso Común en Manejo de Riesgos, AGID reporte no. 13, EAFIT, Medellín, actualizado y reimpreso en Ciudades en Riesgo, Fernández MA (ed) La RED, USAID

Cardona OD (1999a) Diagnóstico local de riesgos naturales en Santa Fe de Bogotá para la planificación y medidas de mitigación. Panamericana-Secretaría de Salud, Bogotá

Cardona OD (1999b) Environmental management and disaster prevention: two related topics. In: Fernandez MA (ed) Cities at risk: environmental degradation, urban risks and disasters in Latin America. A/H Editorial, La RED, US AID, Quito, pp 77-102

Cardona OD (2001). Estimación Holística del Riesgo Sísmico utilizando Sistemas Dinámicos Complejos. Doctoral dissertation, Technical University of Catalonia, Department of Terrain Engineering. Available from: http://www.desenredando.org/public/varios/2001/ehrisusd/index.html

Cardona OD (2004) The need for rethinking the concepts of vulnerability and risk from a holistic perspective: a necessary review and criticism for effective risk management. In: Bankoff G, Frerks G, Hilhorst D (eds) Mapping vulnerability: disasters, development and people. Publishers, London, pp 37-51

Cardona OD (2011) Disaster risk and vulnerability: notions and measurement of human and environmental insecurity. In: Brauch HG, Oswald Spring U, Mesjasz C, Grin J, Kameri-Mbote P, Chourou B, Dunay $\mathrm{P}$, Birkmann J (eds) Coping with global environmental change, disasters and security-threats, challenges, vulnerabilities and risks. Hexagon Series on Human and Environmental Security and Peace, vol 5. Springer, Berlin

Carreño ML (2006) Técnicas innovadoras para la evaluación del riesgo sísmico y su gestión en centros urbanos: Acciones ex ante y ex post. Doctoral dissertation, Technical University of Catalonia, Department of Terrain Engineering. Available from: http://www.tdx.cat/TDX-1102106-110455

Carreño ML, Cardona OD, Barbat AH (2007a) Urban seismic risk evaluation: a holistic approach. Nat Hazards 40(1):137-172

Carreño ML, Cardona OD, Barbat AH (2007b) Disaster risk management performance index. Nat Hazards 41(1): $1-20$

Carreño ML, Cardona OD, Barbat AH (2012) New methodology for urban seismic risk assessment from a holistic perspective. Bull Earthq Eng 10(2):547-565

Chambers Robert (1989) Vulnerability, coping and policy. Inst Dev Stud Bull 20(2):1-7

Cutter S, Finch C (2008) Temporal and spatial changes in social vulnerability to natural hazards. PNAS 105(7):2301-2306

Cutter SL, Boruff BJ, Shirley WL (2003) Social vulnerability to environmental hazards. Soc Sci Q 84(2003):242-261

Cutter S, Barnes L, Berry M, Burton C, Evans E, Tate E, Webb J (2008) A place-based model for understanding community resilience to natural disasters. Glob Environ Change 18(4):598-606

DFID (Department for International Development) (1999) Sustainable livelihood guidance sheets. DFID, London

Folke C (2006) Resilience: the emergence of a perspective for social-ecological systems analyses. Glob Environ Change 16:253-267 
Fuchs S (2009) Susceptibility versus resilience to mountain hazards in Austria—paradigms of vulnerability revisited. Nat Hazards Earth Syst Sci 9:337-352

Füssel HM (2007a) Adaptation planning for climate change: concepts, assessment approaches and key lessons. Sustain Sci 2(2):265-275

Füssel HM (2007b) Vulnerability: a generally applicable conceptual framework for climate change research. Glob Environ Change 17(2):155-167

Füssel HM, Klein R (2006) Climate change vulnerability assessment: an evolution of conceptual thinking. Clim Change 75:301-329

Galaz V, Moberg F, Olsson E-K, Paglia E, Parker C (2011) Institutional and political leadership dimensions of cascading ecological crises. Public Adm 89(2):361-380

Gunderson LH, Holling CS (eds) (2002) Panarchy: understanding transformations in social-ecological systems. Island Press, London

Handmer JW, Dovers SR (1996) A typology of resilience: rethinking institutions for sustainable development. Organ Environ 9(4):482-511

Hewitt K (ed) (1983) Interpretations of calamity. Allen and Unwin, London

Hilhorst D (2004) Complexity and diversity: unlocking social domains of disaster response. In: Bankoff G, Frerks G, Hilhorst D (eds) Mapping vulnerability: disasters, development and people. Earthscan Publishers, London, pp 52-67

Holling C (1973) Resilience and stability of ecological systems. Annu Rev Ecol Syst 4:1-23

ICSU-LAC (2010) Science for a better life: developing regional scientific programs in priority areas for Latin America and the Caribbean. In: Cardona OD, Bertoni JC, Gibbs A, Hermelin M, Lavell A (eds) Understanding and managing risk associated with natural hazards: an integrated scientific approach in Latin America and the Caribbean, vol 2. ICSU Regional Office for Latin America and the Caribbean, Rio de JaneiroCity

IDEA (2005) Indicators of disaster risk and risk management-main technical report. English and Spanish edition, National University of Colombia/Manizales, Institute of Environmental Studies/IDEA, InterAmerican Development Bank, Washington, DC. Available from: http://idea.unalmzl.edu.co

IPCC (2007) Assessing key vulnerabilities and the risk from climate change. In: Parry ML, Canziani OF, Palutikof JP, van der Linden PJ, Hanson CE (eds) Climate change 2007: impacts, adaptation and vulnerability, contribution of working group II to the fourth assessment report of the intergovernmental panel on climate change. Cambridge University Press, Cambridge, pp 7-22

IPCC (2012) Managing the risk of extreme events and disasters to advance climate change adaptation. Special report of the intergovernmental panel on climate change (IPCC). Cambridge University Press, Cambridge

Keiler M, Sailer R, Jörg P, Weber C, Fuchs S, Zischg A, Sauermoser S (2006) Avalanche risk assessmenta multi-temporal approach, results from Galtür, Austria. Nat Hazards Earth Syst Sci 6:637-651

Keiler M, Knight J, Harrison S (2010) Climate change and geomorphological hazards in the Eastern European Alps. Philos Trans R Soc A 368:2461-2479

Kelly PM, Adger WN (2000) Theory and practice in assessing vulnerability to climate change and facilitating adaptation. Clim Change 47(4):325-352

Kienberger S, Lang S, Zeil P (2009) Spatial vulnerability units-expert-based spatial modelling of socioeconomic vulnerability in the Salzach catchment, Austria. Nat Hazards Earth Syst Sci 9:767-778

Lavell A (1999) Environmental degradation, risks and urban disasters. issues and concepts: towards the definition of a research agenda. In: Fernandez MA (ed) Cities at risk: environmental degradation, urban risks and disasters in Latin America. A/H Editorial, La RED, US AID, Quito, pp 19-58

Liverman DM (1990) Chapter 26-vulnerability to global environmental change. In: Kasperson RE, Dow K, Golding D, Kasperson JX (eds) Understanding global environmental change: the contributions of risk analysis and management. Clark University, Worcester, pp 27-44

Maskrey A (1984) Community based hazard mitigation. Disasters mitigation program implementation. Virginia Polytechnic Institute, Virginia

McCarthy JJ, Canziani OF, Leary NA, Dokken DJ, White KS (eds) (2001) Climate Change 2001: impacts, adaptation, and vulnerability. Working group II of the intergovernmental panel on climate change. Cambridge University Press, Cambridge

Mitchell T, van Aalst MK (2009) Convergence of disaster risk reduction and climate change adaptation-a review for DFID. IDS, Brighton

O'Brien K, Eriksen S, Schjolen A, Nygaard L (2004) What's in a word? Conflicting interpretations of vulnerability in climate change research. CICERO working paper, no. 4, CICERO, Oslo University

O'Brien K, Eriksen S, Schjolen A, Nygaard L (2007) Why different interpretations of vulnerability matter in climate change discourses. Clim Policy 7:73-88 
O’Brien K, Sygna L, Leinchenko R, Adger WN, Barnett J, Mitchell T, Schipper L, Tanner T, Vogel C, Mortreux C (2008a). Disaster risk reduction, climate change adaptation and human security. GECHS report 2008, vol 3

O’Brien K, O'Keefe P, Meena H, Rose J, Wilson L (2008b) Climate adaptation from a poverty perspective. Clim Policy 8(2):194-201

Oxfam America (2009) Exposed-social vulnerability and climate change in the US. Southeast Press, Boston

Papathoma-Köhle M, Kappes MS, Keiler M, Glade T (2011) Physical vulnerability assessment for alpine hazards: state of the art and future needs. Nat Hazards 58:645-680

Pelling M (1997) What determines vulnerability to floods; a case study in Georgetown. Guyana, Environ Urban 9(1):203-226

Pelling M (2001) Natural disasters? In: Castree N, Braun B (eds) Social nature. Blackwells, London

Pelling M (2010) Adaptation to climate change: from resilience to transformation. Routledge, London

Pelling M, Dill K (2010) Disaster politics: tipping points for change in the adaptation of sociopolitical regimes. Prog Hum Geogr 34(1):21-23

Phillips BD, Fordham M (2009) Introduction: chapter 1. In: Phillips BD, Thomas DSK, Fothergill A, BlinnPike L (eds) Social vulnerability to disasters. CRC Press, Boca Raton

Quarantelli EL (1998) What is a disaster?. Routledge, New York

Renaud FG (2006) Environmental components of vulnerability. In: Birkmann J (ed) Measuring vulnerability to natural hazards: towards disaster resilient societies. United Nations University Press, Tokyo, pp 117-127

Renn O (2008) Risk governance-coping with uncertainty in a complex world. Earthscan, London

Romieu E, Welle T, Schneiderbauer S, Pelling M, Vinchon C (2010) Vulnerability assessment within climate change and natural hazard contexts: revealing gaps and synergies through costal applications. Sustain Sci 5(2):159-170

Thomalla F, Downing T, Spanger-Siegfried E, Han G, Rockström J (2006) Reducing hazard vulnerability: towards a common approach between disaster risk reduction and climate adaptation. Disasters 30(1):39-48

Timmerman P (1981) Vulnerability, resilience and the collapse of society. Environmental monograph no. 1. Institute for Environmental Studies, University of Toronto, Toronto

Turner BL, Kasperson RE, Matson PA, McCarthy JJ, Corell RW, Christensen L, Eckley N, Kasperson JX, Luers A, Martello ML, Polsky C, Pulsipher A, Schiller A (2003) A framework for vulnerability analysis in sustainability science. In: PNAS (Proceedings of the National Academy of Sciences), vol 100, no. 14, pp 8074-8079

UNDRO (1980) Natural disasters and vulnerability analysis. Report of experts group meeting of 9-12 July 1979, Geneva

UNISDR (2004) Living with risk. UNISDR, Geneva

UNISDR (2009) Terminology on disaster risk reduction, Geneva. Available from: http://unisdr.org/ eng/library/lib-terminology-eng.htm

Vayda AP, McCay B (1975) New directions in ecology and ecological anthropology. Annu Rev Anthropol 4:293-306

Vester F (2008) Die Kunst vernetzt zu denken-Ideen und Werkzeuge für einen neuen Umgang mit Komplexität. Deutscher Taschenbuch Verlag, München

Vichon C, Carreño M-L, Contreras-Mojica DM, Kienberger S, Schneiderbauer S, Alexander D, Barbat AH, Cardona OD, Decker B, Eidsvig U, Papathoma-Köhle M, Miniati R, Pratzler-Wanczura S, Ulbrich T, Vangelsten BV, Welle T (2011). Assessing vulnerability to natural hazards in Europe: from principles to practice. A manual on concept, methodology and tools. MOVE deliverable no. 4.2., Available from: http://www.move-fp7.eu/documents/MOVE_Manual.pdf

Wisner B (2006) Self-assessment of coping capacity: Participatory, proactive, and qualitative engagement of communities in their own risk management. In: Birkmann J (ed) Measuring vulnerability to natural hazards - towards disaster resilient societies. United Nations University Press, Tokyo, pp 316-328

Wisner B, Blaikie P, Cannon T, Davis I (2004) At risk, natural hazards. People's Vulnerability and Disasters, Routledge

Yohe G, Tol RSJ (2002) Indicators for social and economic coping capacity: moving toward a working definition of adaptive capacity. Glob Environ Change 12(1):25-40 